УДК 316.42 (512.36)

БАДАРАЕВ Дамдин Доржиевич - кандидат социологических наук; доцент, старший научный сотрудник Института монголоведения, буддологии и тибетологии СО РАН (670047, Россия, Республика Бурятия, г. Улан-Удэ, ул. Сахьяновой, 6; damdin80@таil.ru)

\title{
ТУРБУЛЕНТНОСТЬ В МОНГОЛИИ: НОВАЯ ВОЛНА СОЦИАЛЬНО-ПОЛИТИЧЕСКИХ ВЫЗОВОВ
}

Аннотация. В статье рассмотрены особенности социально-политического кризиса в современной Монголии как выражение новой волны турбулентности. На основе анализа интернет-источников показаны назревшие внутренние противоречия в монгольском обществе, которые вылились в политические митинги в конце 2018 - начале 2019 г. Данные показывают, что в Монголии еще не сформирована стабильная и эффективная политическая система. Как результат, наблюдаются периодические спады и подьемы не только в политике, но и в экономике и социальной сфере. Страна находится в поиске оптимальной модели политического устройства.

Ключевые слова: политический кризис, политическая система, турбулентность, митинги, Монголия

$\mathrm{B}^{\mathrm{s}}$ условиях мировых социально-экономических и политических кризисов многие страны преодолевают вызовы современности с переменным успехом. Монголия не является исключением, поскольку в постсоциалистическом пространстве она полностью переориентировалась на путь демократизации, на котором страна периодически попадает в кризисные, турбулентные зоны. Монголия является страной резких контрастов, ее особенности можно рассматривать с позиции внешней и внутренней оценки.

Во внешнем измерении Монголия представляет собой суверенное государство. На международной арене она характеризуется в качестве объекта геополитической борьбы таких крупных игроков, как Россия и Китай (непосредственные соседи), а также группы передовых стран под общим названием «третий сосед» (США, Япония, Республика Корея, Великобритания, Канада, Германия, Франция и др.) [Родионов 2018: 278]. Главным инструментом в условиях конкуренции за лидерство в «большой игре» выступают методы «мягкой силы». Политика Монголии, основанная на принципах многоопорности, позволяет маневрировать и лавировать в лабиринте международных интересов, привлекая инвесторов, партнеров и туристов из других стран богатыми минеральносырьевыми запасами, выгодным геополитическим положением, богатой историей, спецификой традиционной культуры и т.д. Несмотря на благоприятный внешний историко-культурный и геополитический образ на международной арене, для политического курса современной Монголии характерны перманентные внутренние противоречия.

С позиции внутреннего оценивания Монголия на постсоциалистическом пространстве переориентировалась на плюрализацию власти, свободные выборы, свободу слова, митингов и демонстраций, активность неправительственных организаций, рыночную экономику. Монгольский пример достижения демократии претендует на роль образца демократии в Центральной и Восточной Азии.

Вместе с тем оценка внутреннего содержания монгольской демократии показывает, что постсоциалистическая политическая система Монголии характеризуется нестабильностью и кризисами, проявляющимися с определенной регулярностью. На пути демократизации монгольского общества встречаются 
достаточно серьезные издержки и противоречия. Частая смена правительства (18 раз за постсоциалистический период, т.е. с 1990 г. каждое правительство работало в среднем менее 2 лет), скандалы в парламенте страны, нестабильность и противоречивость принятых законов, совмещение обязанностей члена кабинета министров и члена парламента, коррупция, аресты бывших первых лиц, в т.ч. и бывшего президента Намбарына Энхбаяра, экс-премьеров Санижийна Баяра и Чимэдийна Сайханбилэга, потеря инвестиционного имиджа в связи со скандалами в горнорудной отрасли демонстрируют перманентную нестабильность политической системы страны. Комплекс причин и факторов сдерживает прогрессивное развитие и негативно отражается на социальном благополучии монгольского общества, способствует поляризации и дифференциации населения страны.

В совокупности с негативными экономическими и социальными смежными факторами политическая система в современной Монголии периодически оказывается в зоне турбулентности и, по мнению многих политиков, политологов и исследователей, переживает кризис. По данным социологических опросов академических институтов и Центра изучения общественного мнения «Сантмарал», доверие граждан страны к партиям и существующей политической системе снижается [Монголы в зеркале... 2015].

В Монголии пока еще не сформировалась стабильная и эффективная политическая система. Там развернулась борьба за власть между несколькими группировками, в которых тесно переплелись партийные, политические и бизнесинтересы политических деятелей и крупных бизнесменов (нередко - в одном лице). Многие монгольские политики, политологи и юристы считают, что современная политическая система становится тормозом для политического и социально-экономического прогресса страны и нуждается в дальнейшем совершенствовании [Грайворонский 2017: 61].

Рассматривая наиболее критические периоды в развитии «новой Монголии» за последние четверть века с учетом политических, экономических и социальных факторов, можно условно выделить следующие турбулентные зоны/этапы с их основными кризисными чертами [Бадараев 2015: 203-204].

Первая турбулентная зона - 1991-1993 гг:: резкое прекращение советского экономического патронажа, приватизация, инфляция (уровень ВВП снизился более чем на $30 \%$, в 1991 г. - до 9,2\%, почти 1/4 часть населения оказалась за чертой бедности, численность безработных составила более 70 тыс. чел., уровень инфляции в 1992 г. достиг 325\%).

Вторая турбулентная зона - 1998 - нулевые годы: последствия неудачного опыта демократов - отставка правительства демократов; мировой финансовый кризис 1998 г.; существенное ухудшение положения страны на конец 1999 г. по ряду показателей, таких как внутренняя и внешняя задолженность, бюджетный дефицит, внешняя торговля и др.; сильнейший дзут (стихийное бедствие, сопровождающееся бескормицей) 1998-1999 и 1999-2000 гг., при котором потери скота составили до 10 млн голов.

Третья турбулентная зона - 2008-2010 гг.: июльская революция 2008 г., (вследствие беспорядков погибли 5 чел., 300 чел., в т.ч. 100 полицейских, получили ранения, 760 чел. были арестованы), финансовый кризис 2008 г. привел к снижению ВВП в 2009 г. до 1,3\%, сильнейший дзут 2009-2010 гг. (потери скота составили 8 млн голов).

Отмеченные зоны/этапы турбулентности продемонстрировали закономерность повторов с 7-10-летним циклом.

Имеющиеся проблемы в политике, экономике и социальной сфере в постсоциалистической Монголии дают основания полагать, что нарастающие 
«завихрения» переросли в очередную - четвертую - волну турбулентности. Политический накал в Монголии в 2018 - начале 2019 г. вполне соответствует основным признакам новой волны турбулентности. В связи с назревшим политическим кризисом в конце 2018 г. прошли несколько митингов на площади Сухэ-Батора. Политическая борьба между премьер-министром страны Ухнаагийном Хурэлсухом и председателем Великого государственного хурала Миеэгомбыном Энхболдом вышла на новый уровень, получила широкий общественный резонанс и затронула широкие слои населения и общественные организации.

14 ноября 2018 г. прошел митинг с требованиями привлечь к ответственности парламентариев и министров, которые фигурируют в деле о получении льготного кредита в Фонде развития малого и среднего предпринимательства. Митинг возглавили ряд общественных движений Монголии ${ }^{1} .19$ ноября 27 членов парламента Монголии требовали отправить правительство в отставку 2 . Ответная реакция последовала в форме бойкота, который продолжался более месяца, когда 40 членов ВГХ от правящей Монгольской народной партии и меньшинства в ВГХ от Демократической партии, поддерживающих председателя МНП, премьер-министра У. Хурэлсуха, не участвовали в заседаниях сессии парламента и постоянных комитетов ВГХ. Бойкотировавшие требовали «принудительного выселения» председателя ВГХ М. Энхболда из его рабочего кабинета, угрожая тем, что начнут очередную волну борьбы по стране, объявят сидячую забастовку, а в дальнейшем выберут жесткую форму борьбы. Они вызвали ажиотаж в монгольском обществе и «разбудили» общественные движения ${ }^{3}$.

Назревшее противостояние между руководителями исполнительной и законодательной ветвей власти Монголии продолжилось в виде массовой демонстрации с выходом митингующих на площадь Сухэ-Батора в столице страны в декабрьские тридцатиградусные морозы 2018 г. Основное требование митингующих - отставка спикера - аргументировалось его причастностью к скандальному «делу о 60 миллиардах» (обещание некоторых высокопоставленных политиков предоставить должности в госорганах в обмен за денежное вознаграждение по итогам парламентских выборов 2016 г.), к деятельности неформальной группы МАНАН (досл. - «туман»; союз двух партий МАН и АН, Монгольской народной партии и Демократической партии) и допущением крупных политических просчетов, что привело к кризисам последних лет. Спикер выступил с ультиматумом о законной процедуре своей отставки, аргументируя сложившуюся кризисную ситуацию системными факторами, а не только его личными ошибками.

По разным оценкам, 27 декабря 2018 г. на акции протеста за отставку М. Энхболда с поста председателя ВГХ присутствовали на площади Д. СухэБатора от 10 до 20 тыс. чел. Внимание всех СМИ было приковано к данной демонстрации. Прямую трансляцию на канале YоиТиbe вел Д. Дагвадорж, известный в прошлом сумоист, пользующийся широкой популярностью среди населения, который начал заниматься общественно-политической деятельностью после завершения профессиональной спортивной карьеры в Японии ${ }^{4}$.

\footnotetext{
1 Митинг с требованиями о привлечении к ответственности парламентариев и министров. 2018. Доступ: http://www.mongolnow.com/miting-s-trebovaniyami (проверено 10.04.2018).

2 Депутаты парламента Монголии потребовали отставки спикера. 2018. Доступ: https://regnum.ru/ news/2524316.html (проверено 15.04.2019).

3 Не за горами начало второй волны акта протеста. 2018. Доступ: http://www.mongolnow.com/ne-zagorami (проверено 20.04.2019).

4 Дагвадорж принял участие в демонстрации и провел прямую трансляцию. 2018. Доступ: https:// www.youtube.com/watch?v=QC0-x4ICSe4 (проверено 10.05.2019).
} 
По сравнению с массовыми беспорядками июля 2008 г. формат мероприятия, его организованность и спланированность позволили избежать каких-либо инцидентов и фактов провокаций, демонстрируя цивилизованность волеизъявления и гражданскую ответственность. Примечательно, что впервые за 10 лет организаторам мирной демонстрации удалось собрать столь большую массу людей, причем в холодное время года.

Позиция М. Энхболда оставалась неизменной, пока политические противники не усилили свое давление. Согласно инициированному и внесенному на утверждение ВГХ президентом Монголии закону, на основании которого можно освобождать председателя ВГХ, большинством голосов парламентариев М. Энхболд был освобожден с поста спикера ВГХ. За его отставку проголосовали 43 из 65 присутствовавших на заседании членов парламента.

Отставка спикера и назначение на пост председателя ВГХ начальника Управления по делам Правительства, члена ВГХ Гомбожавына Занданшатара означало, что законодательная и исполнительная ветви власти Монголии близки к общему пониманию проблемы сохранения социальной стабильности в обществе и недопущения эскалации массовых выступлений. Но вместе с тем политическая повестка остается прежней, и многие вопросы социально-экономического плана, коррупционные дела, проблемы горнорудной промышленности продолжают волновать общественность страны.

Экономический блок вопросов также свидетельствует об имеющихся проблемных зонах, которые на данном этапе больше связаны с политическим кризисом. Экономика в начале 2019 г. демонстрирует улучшение показателей по сравнению с предыдущими годами. Например, рост ВВП Монголии за 2018 г. составил 6,9\%, по прогнозам Всемирного банка за 2019 г. ВВП Монголии поднимется до уровня 7,2\%, а в 2020 г. составит 6,9\%. Уровень инфляции на апрель 2019 г. составил 7\%1. Как показывает практика, экономические проблемы на макроуровне связаны с горнорудной отраслью. Общественный резонанс получили незавершенность договорных дел и затянувшиеся переговоры по проектам освоения крупных месторождений меди и золота в Оюутолгое относительно пересмотра условий подписанного соглашения между правительством Монголии и австралийской компанией «Рио Тинто»; расследование сделки о покупке российской доли акций крупных промышленных компаний «Предприятие Эрдэнэт» и «Монголросцветмет» через подставные банки. По объективным причинам, связанным с экономическим и финансовым кризисами в мире, падением инвестиционного имиджа, внутренними политическими коллизиями, экономика страны недополучает ожидаемые налоговые поступления и дивиденды от горнорудного бизнеса. Число ищущих работу в Монголии к концу февраля 2019 г. составило 33,9 тыс. (из них 12,6 тыс. - женщины). Более 7\% безработных зарегистрированы в Улан-Баторе, 25,8\% - в зоне Хангая, 4,3\% - в западной части страны, 14,3\% - в центральной части, 10,3\% - в восточной части. Несмотря на официальные данные, для Монголии показатели фактической безработицы и бедности всегда остаются на высоком уровне 2 .

Экологические вопросы также дополняют перечень проблемных вопросов: общественность регулярно требует оперативного разрешения проблемы загрязнения воздуха в столице страны. Письмо с подписями 50 тыс. граждан Монголии дошло до своего адресата - ООН. Организация Air Visual обнародовала список 100 городов мира с наибольшим уровнем загрязнения воздуха.

\footnotetext{
1 ВВП Монголии в первом квартале 2019 года вырос на 8,6\%. 2019. Доступ: http://asiarussia.ru/ news/21833/ (проверено 20.04.2019).

2 Безработица в Монголии. Немного статистики. 2019. Доступ: http://www.mongolnow.com/ bezrabotitsa-v-mongolii (проверено 10.04.2019).
} 
Столица Монголии Улан-Батор находится на 72-м месте по показателям индекса качества воздуха с результатами в 58,51. По некоторым оценкам, загазованность столицы страны в пиковые периоды превышает в сотни раз нормальные показатели. Как известно, загазованность связана с использованием в качестве топлива угля и бытовых отходов (в т.ч. покрышек, использованных моторных масел) многочисленными юрточными микрорайонами/кварталами (гэрхороолол), где в основном проживают малообеспеченные приезжие слои населения. Перед столичными властями возникает целый ряд взаимоувязанных проблем, требующих безотлагательного решения. В этом плане повышенная концентрация населения в Улан-Баторе и его пригородах также является одной из причин возникновения турбулентности. Загазованность столицы, автомобильные пробки и другие актуальные социальные проблемы часто упоминаются в политических программах в период предвыборных кампаний кандидатов и партий.

Политический кризис в Монголии говорит о новой волне турбулентности в Монголии именно на фоне заметных политических событий 2018 г. «Существующая политическая система Монголии во многом исчерпала свой потенциал, стала в какой-то степени тормозом в развитии страны и нуждается в совершенствовании» [Грайворонский 2017: 29]. Преодоление вызовов новой волны политической турбулентности потребует решения внутренних противоречий между представителями оппозиционных партий, доведения до логического завершения затяжных скандалов в горнорудной отрасли, коррупционных дел, решения проблем социально-экономического плана (поднятие уровня жизни граждан и другие актуальные вопросы, требующие незамедлительного разрешения). Между тем вырисовываются вполне определенные перспективы выстраивания долгосрочных проектов сотрудничества Монголии со своими соседями в рамках экономических коридоров между тремя странами. Перед политическим руководством Монголии стоят сложные задачи сохранения имиджа страны на международной арене и в то же время - преодоления назревших внутренних вызовов.

Работа выполнена в рамках государственного задания (проект ХII.191.1.1. «Трансграничье России, Монголии и Китая: история, культура, современное общество», номер госрегистрации № АAAA-A17-117021310269-9).

\section{Список литературы}

Бадараев Д.Д. 2015. Влияние «турбулентности» на модернизационные процессы в монгольском обществе. - Власть. Т. 23. № 4. С. 201-205.

Грайворонский В.В. 2017. Монголия в начале ХХІ в. (политика, экономика, общество). М.: Изд-во ИВ РАН. 352 с.

Монголы в зеркале социологии: сборник материалов социологических исследований. 2015. Улан-Батор: Институт философии, социологии и права АН Монголии. № 3. 182 с.

Родионов В.А. 2018. Политический процесс в Монголии в условиях постсоциалистической трансформации (науч. ред. А.С. Железняков). Улан-Удэ: Изд-во Бурятского госуниверситета. 340 с.

\footnotetext{
1 Монгольская столица на 72-ом месте по показателям загрязнения воздуха. 2019. Доступ: http:// www.mongolnow.com/mongolskaya-stolitsa (проверено 10.04.2018).
} 
BADARAEV Damdin Dorzhievich, Cand.Sci. (Soc.), Associate Professor, Senior Research Associate of the Institute for Mongolian, Buddhist and Tibetan Studies, Siberian Branch of Russian Academy of Sciences (6 Sakhyanovoj St, UlanUde, Republic of Buryatia, Russia, 670047; damdin80@mail.ru)

\title{
TURBULENCE IN MONGOLIA: THE NEW WAVE OF SOCIAL AND POLITICAL CHALLENGES
}

Abstract. The article discusses the features of the socio-political crisis in modern Mongolia as an expression of a new wave of turbulence. Based on an analysis of Internet sources, the author shows the imminent internal contradictions in Mongolian society, which resulted in political demonstration at the end of 2018. The data show that a stable and effective political system has not yet been formed in Mongolia. As a result, there are periodic ups-and-downs not only in politics, but also in the economy and the social sphere. The country is in search of an optimal model of political structure.

Keywords: political crisis, political system, turbulence, protest rallies, Mongolia

КАРСАНОВА Елена Созрикоевна - доктор политических наук, доцент департамента политологии и массовых коммуникаций Финансового университета при Правительстве РФ (1255993, Россия, г. Москва, Ленинградский пр-кт, 49; e_karsanova@mail.ru)

\section{ГЕНЕЗИС ШВЕЙЦАРСКОГО ЕВРОСКЕПТИЦИЗМА}

\begin{abstract}
Аннотация. Предлагаемая статья посвящена краткому рассмотрению основных причин неприятия швейцарцами идеи европейской интеграции. Евроинтеграция для Швейцарии означает не только сокращение компетенций референдарной демократии и упразднение нейтралитета, что равнозначно утрате национальной идентичности, но и приобретение швейцарцами элементов европейских практик и наднациональных институтов. Генезис швейцарского евроскептицизма автор, прежде всего, связывает с приверженностью швейцарского электората к отечественным политическим институтам, угрозой сокращения компетенций институтов нейтралитета, федерализма и референдарной демократии, неприятием швейцарским электоратом элементов европейских практик.
\end{abstract}

Ключевые слова: Швейцария, Европейский союз, евроскептицизм, евроинтеграция, нейтралитет, федерализм, демократия

Д о сегодняшнего дня Швейцарская конфедерация последовательно выступает против вступления в Европейский союз и Европейскую экономическую зону. Даже в условиях Brexit швейцарский евроскептицизм представляется на первый взгляд озадачивающим. Швейцария - небольшая страна, не располагающая солидным запасом природных ресурсов, не имеющая выхода к морю, во многом зависящая от внешнеторговых отношений, казалось бы, должна стремиться к экономической интеграции с остальной частью Европейского континента [Швейцер 2009]. Тем не менее большая часть швейцарского электората считает, что членство в Евросоюзе ставит под угрозу собственную внутреннюю интеграцию полиэтнической федерации.

В самых общих чертах экономическое положение Швейцарии мало чем отличается от экономически благополучных европейских стран, которые стремятся к более тесной интеграции. При этом нежелание швейцарцев вступать в какие- 